\section{Geological evidence of tsunamis and earthquakes at the Eastern Hellenic Arc: correlation with historical seismicity in the eastern Mediterranean Sea}

\author{
Gerassimos A. Papadopoulos, \\ Koji Minoura, ${ }^{2}$ Fumihiko Imamura, ${ }^{3}$ \\ Ugur Kuran, ${ }^{4}$ Ahmet Yalçiner, ${ }^{5}$ \\ Anna Fokaefs, ${ }^{1}$ Tomoyuki Takahashi ${ }^{6}$ \\ 'Institute of Geodynamics, National \\ Observatory of Athens, Athens, Greece; \\ 'Institute of Geology and Paleontology, \\ Faculty of Science, Tohoku University, \\ Sendai, Japan; ${ }^{3}$ Disaster Control Research \\ Center, Faculty of Technology, Tohoku \\ University, Sendai, Japan; ${ }^{4}$ Earhquake \\ Research Department, Ministry of Public \\ Works and Resettlement, Lodumlu, \\ Ankara, Turkey; ${ }^{5}$ Coastal and Harbor \\ Engineering Research Center, Civil \\ Engineering Department, Middle East \\ Technical University, Ankara, Turkey; \\ ${ }^{6}$ Faculty of Safety Science, Kansai \\ University, Osaka, Japan
}

\section{Abstract}

Sedimentary stratigraphy determined by trenching in Dalaman, south-western Turkey, revealed three sand layers at a distance of approximately $240 \mathrm{~m}$ from the shoreline and at elevations of $+0.30,+0.55$ and $+0.90 \mathrm{~cm}$. Storm surge action does not explain the features of these deposits that show instead typical characteristics of tsunami deposition. The sand layers correlate with historical tsunamis generated by large earthquakes which ruptured the eastern Hellenic Arc and Trench in 1303, 1481 and 1741. Accelerator mass spectrometry ${ }^{14} \mathrm{C}$ dating of a wood sample from layer II indicated deposition in $\mathrm{AD} 1473 \pm 46$, which fits the 1481 event. From an estimated average alluvium deposition rate of approximately $0.13 \mathrm{~cm} /$ year, layers I and III were dated at 1322 and 1724, which may represent the large 1303 and 1741 tsunamis. The geological record of the 1303 key event is very poor; therefore, sand layer I perhaps represents an important geological signature of the 1303 tsunami. However, the strong tsunami reported to have been generated by the 1609 earthquake is missing from Dalaman stratigraphy: this underlines the sensitivity of tsunami geological signatures to various local factors. The 1303 earthquake ruptured the trench between the islands of Crete and Rhodes. For the earthquakes of 1481, 1609 and 1741 we suggested that they were very likely generated in the Rhodes Abyssal Plain where sea depths of up to approximately $4200 \mathrm{~m}$, together with the thrust component of seismotectonics, favor tsunami generation. Sand dykes directed upwards from layer I to layer II indicated that the 1481 earthquake triggered liquefaction of sand layer I. The results substantially widen our knowledge about the historical earthquake and tsunami activity in the eastern Mediterranean basin.

\section{Introduction}

The Hellenic Arc and Trench (HA-T) system in the eastern Mediterranean basin is a very active seismotectonic structure that has produced shallow and intermediate-depth earthquakes of magnitudes (M) up to approximately 8.0 with a mean return period of around 600 years. HA-T seismotectonics are controlled by: i) the active subduction of the African lithosphere from SSW to NNE beneath the overriding Eurasian plate (Figure 1);1,2 ii) the counterclockwise rotation of the African lithosphere relative to Eurasia along the Hellenic Trench at rates in the range of 20-30 mm/year; 3 iii) the rollback of the subducting lithosphere beneath the Hellenic Trench. ${ }^{4}$ Global positioning system (GPS) measurements of crustal motions indicated that the central and southern Aegean is characterized by coherent motion, with small internal deformation of less than $2 \mathrm{~mm} /$ year, toward the SW at $30 \pm 1$ $\mathrm{mm} /$ year relative to Eurasia. ${ }^{5}$ Stations in the SE Aegean, however, deviate significantly from the overall motion of the southern Aegean, showing increasing velocities toward the trench and reaching $10 \pm 1 \mathrm{~mm} /$ year relative to the southern Aegean as a whole.

In the eastern segment of the system, hereafter called EHA-T, focal mechanisms of earthquakes indicated that the plate motion is leftlateral oblique with thrust component (Figure 2). ${ }^{1,2,6,7,8}$ The northwards continuation of the EHA-T in SW Turkey is the so-called FethiyeBurdur Zone of shear tectonics. GPS-determined velocity field shows left-lateral shear strain rates reaching 80 nstrain/year in the Pliny-Strabo troughs ${ }^{9}$ The largest (M 7.2) shallow earthquake in the instrumental period of seismology was the lethal main shock of $25^{\text {th }}$ April 1957, which ruptured offshore to the northeast of the island of Rhodes, Greece, and caused extensive destruction mainly in Rhodes city (Figure 2). No tsunami was reported in association with that earthquake. However, documentary sources leave no doubt that large historical earthquakes generated very strong tsunamis and, therefore, the EHA$\mathrm{T}$ has been considered to be a zone of high tsunami potential. ${ }^{10,11}$

The geological identification of palaeot-
Correspondence: Gerassimos A. Papadopoulos, Institute of Geodynamics, National Observatory of Athens, P.0. Box 20048, Athens, Greece. Tel/Fax: +30-210-3490165.

E-mail: papadop@noa.gr

Key words: palaeotsunami, sediment deposits, seismicity, Eastern Mediterranean.

Acknowledgments: the contribution of the Japanese team was supported by special funds of the Ministry of Education, Culture, Sport, Science \& Technology, Japan (MEXT), for the promotion of Science and Technology. The first author acknowledges financial support from the Prefecture of Dodecanese (Greece). U. Kuran and A. Yalciner were partly supported by research grants provided by the Middle East Technical University (METU, Project n. AFP-2001-03-03-06) and TUBITAK (Projects n. YDAB.C.AG 60 and INTAG 827). G.A. Papadopoulos and A. C. Yalciner are thankful to the IOC/UNESCO for a field trip grant. Historical documentation of the earthquake/tsunami events was studied by the National Observatory of Athens team in the frame of the research project Tsunami Risk ANd Strategies For the European Region (TRANSFER), Commission of European Communities, contract n. 037058, FP6-2005-Global-4. The GMT software (Wessel and Smith, 1998) was used to plot Figures 1,2 and 3. Thanks are due to three anonymous reviewers who suggested helpful comments which helped us to improve significantly the initial manuscript submitted.

Contributions: FI, UK, KM, GAP, TT, AY participated at the field surveys in Dalaman and Rhodes; FI coordinated the field surveys; AY, UK performed field inspection to prepare the field survey in Dalaman; KM analyzed and interpreted the sediment deposits, supervised AMS $14 \mathrm{C}$ dating and wrote section 4 of the paper; GAP wrote the rest part of the paper; AF, UK compiled historical documentation of earthquakes and tsunamis; AF prepared Figures 1, 2, 3, 5 and 6.

Received for publication: 18 April 2011. Revision received: 28 September 2012. Accepted for publication: 3 October 2012.

This work is licensed under a Creative Commons Attribution NonCommercial 3.0 License (CC BYNC 3.0).

(C) Copyright G.A. Papadopoulos et al., 2012 Licensee PAGEPress, Italy

Research in Geophysics 2012; 2:e12

doi:10.4081/rg.2012.e12

sunamis from sediment deposits and their correlation with historical earthquakes and volcanic eruptions has been proved to be quite successful in the eastern Mediterranean basin, e.g. on the island of Crete; ${ }^{12-16}$ on the island of Thera; ${ }^{11,17}$ in south-western Turkey, ${ }^{14}$ in Israel ${ }^{18}$ and in the Gulf of Corinth, Central Greece. ${ }^{19-21}$ 
Earthquake and tsunami events in the tectonic segment of EHA-T have a long history and several have been historically documented. The largest event was that of $8^{\text {th }}$ August 1303 with an around $8 \mathrm{M}$ earthquake and a tsunami which flooded coastal zones in the entire basin of the eastern Mediterranean. From this point of view, it is of general methodological interest to look for geological signatures of tsunamis and to test how this correlates with the historical documentation. On the other hand, the high tsunami potential associated with the EHA-T calls for an assessment of tsunami hazard that is as reliable as possible. This, however, requires a better understanding of the seismic tsunamigenic sources as well as of the rate of tsunami generation. Here we present new results concerning a sequence of three tsunami sediment layers identified by trenching in the coastal zone of Dalaman, south-western Turkey (Figure 1). The three tsunamis identified geologically were dated and correlated with historically documented tsunamis generated very possibly by large earthquakes in the EHA-T (Appendix).

\section{Historical earthquake and tsunami record}

Thanks to the long history of the region of EHA-T, particularly of the island of Rhodes, documentary sources reporting earthquakes and tsunamis date from as early as the $3^{\text {rd }}$ century BC (for more details see Appendix). A historical record of earthquakes and tsunamis occurring in EHA-T has been compiled and discussed in a large number of catalogs, books and other publications.,22-38 Papadopoulos et $a l .{ }^{39}$ critically evaluated the available documentary sources, added new observations from field surveys, and compiled a new EHA-T tsunami catalog arranged according to the standards established for the New European Tsunami Catalogue by a large number of scientists working together on several tsunami research projects financed by the European Commission. ${ }^{40,41}$ The pre-historic large Minoan tsunami was documented geologically also in the area of EHA-T. This exceptional event is briefly reviewed below.

The time interval covered by our palaeotsunami stratigraphy in Dalaman covers the last seven centuries. From the events pre-dating our stratigraphy record, the only known pre-historic tsunami is the so-called Minoan tsunami which was produced by the Late Bronze Age (LBA) giant eruption of the Thera volcano of Volcanic Explosivity Index 7+, very possibly in the second half of $17^{\text {th }}$ century BC. The LBA tsunami has been documented by sediment deposits found in several coastal localities near EHA-T, such as on the island of

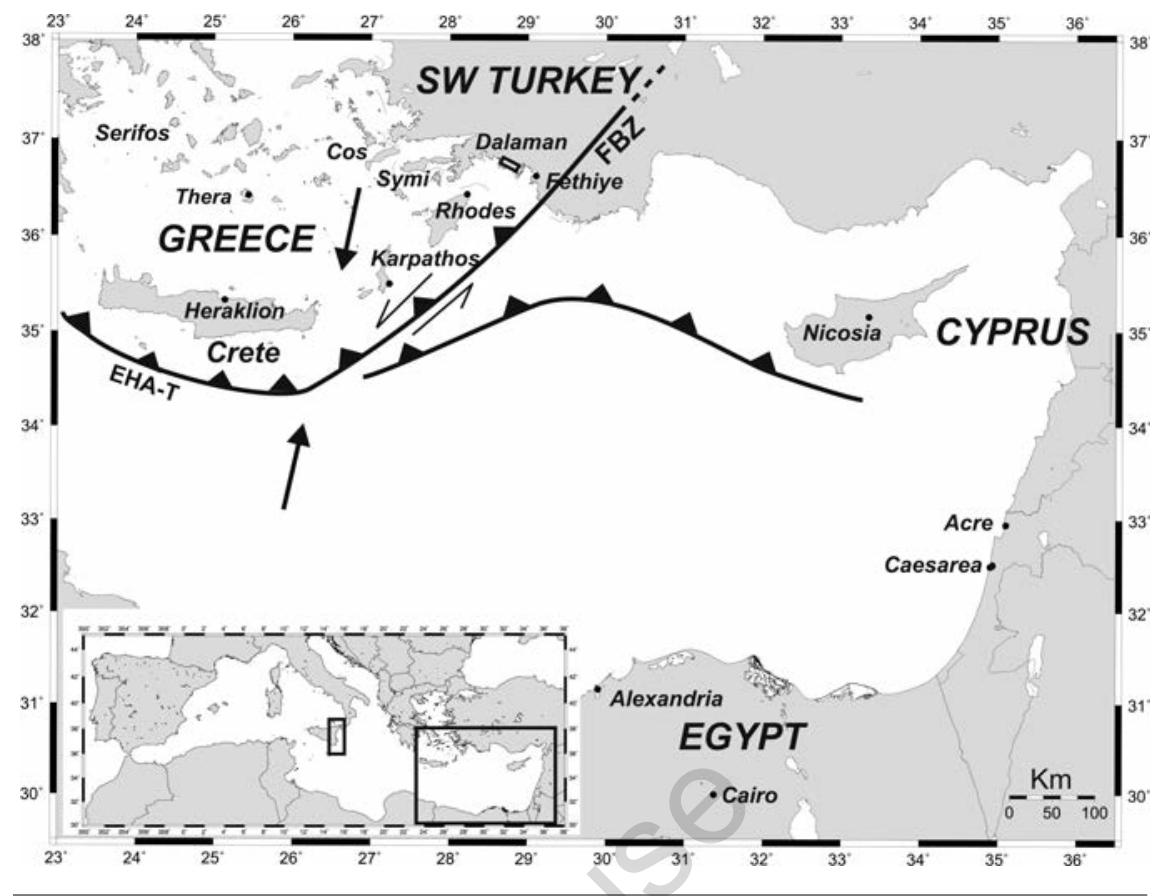

Figure 1. Main seismotectonic features in the region of the Eastern Hellenic Arc and Trench (EHA-T) where the African lithosphere under thrusts beneath the Eurasian plate along the Hellenic Arc and the Cyprean Arc. Arrows indicate the direction of lithospheric plate motions. In the eastern segment of the EHA-T, the motion becomes oblique and continues in Fethiye-Burdur Zone (FBZ), southwest Turkey, as a left-lateral strike-slip fault zone. The surveyed areas of Rhodes in Greece and of Dalaman in southwestern Turkey are shown. Small inset shows the area of eastern Sicily where tsunami sediment deposits were found that possibly correspond to the Minoan tsunami of the $17^{\text {th }}$ century BC (see text for details).

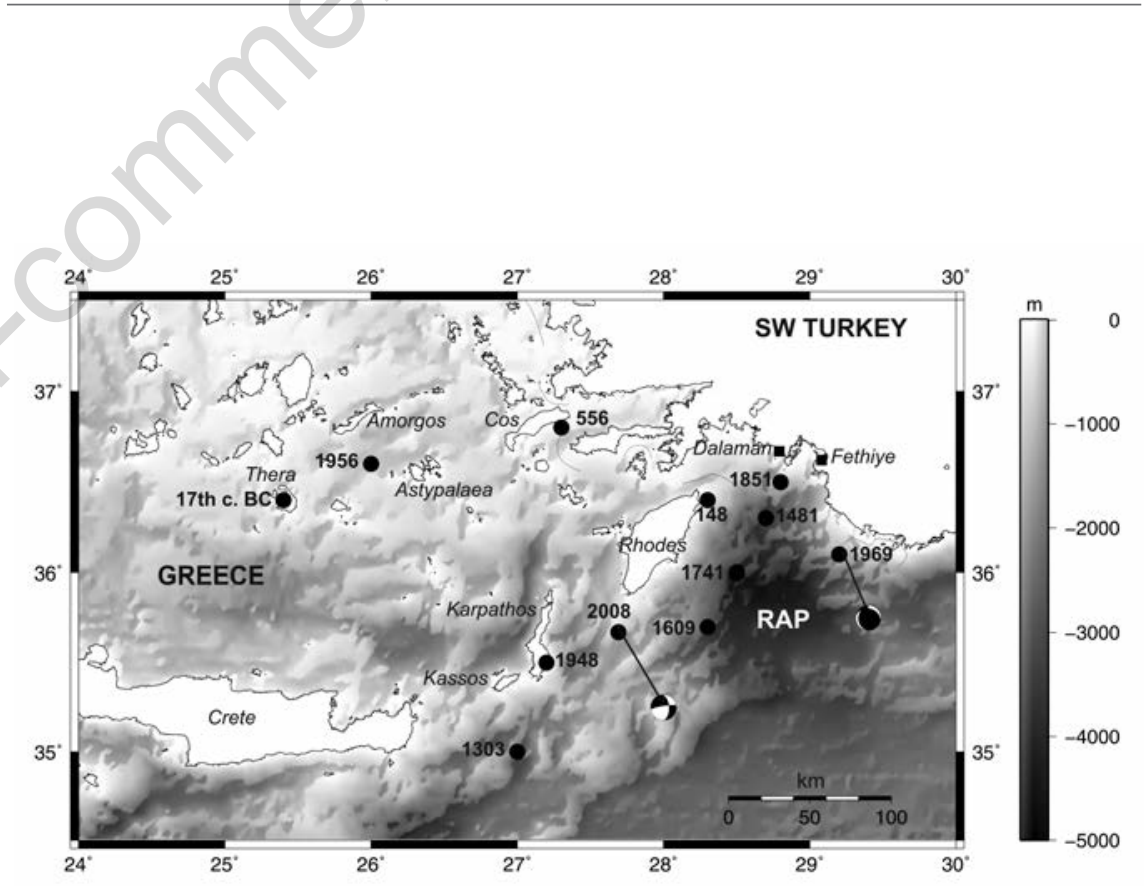

Figure 2. Epicentral locations (solid circles) and year of occurrences of the historical tsunamigenic earthquakes in the Eastern Hellenic Arc and Trench (EHA-T) and the surrounding regions. The source of the $17^{\text {th }}$ century $B C$ tsunami produced by the Minoan eruption on Thera is also plotted. RAP, Rhodes Abyssal Plain. To indicate the seismotectonics of the region, the focal mechanisms (beach-ball diagrams) of the 1969 and 2008 strong, non-tsunamigenic earthquakes are plotted (from Papazachos and Papazachou, 2003, and references therein for 1969; from the Harvard list of Centroid Moment Tensor solutions, http://www.globalcmt.org/CMTsearch.html for 2008). Focal parameters of all earthquakes are listed in Table 1. 
Thera, in northern Crete and in south-western Turkey ${ }^{11,14-17}$ and possibly further away in eastern Sicily ${ }^{42}$ (Figure 1). Characteristic sea bottom deposits, called homogenites, were also attributed to the passage of the Minoan tsunami. ${ }^{43,44}$ In addition, a sedimentary deposit on the continental shelf off Caesarea Maritima, Israel (Figure 1), collected in four cores from 10 to $20 \mathrm{~m}$ water depths, was identified, dated and attributed to tsunami waves produced during the LBA eruption of Thera. ${ }^{18}$

In the classical period, reporting of strong earthquakes and tsunamis in Greece, including the structure of HA-T, goes back at least to the $3^{\text {rd }}$ century $\mathrm{BC}$, and in some areas even earlier. Event statistics indicated that the reporting increased quasi-exponentially from the $15^{\text {th }}$ century AD onwards. ${ }^{39,45,46}$ To investigate historical tsunami events which possibly correlate with the tsunami sediment deposits described in the next section, we reviewed historical documentation of earthquakes and tsunamis occurring in the EHA-T region from antiquity up to the present day. Parameters of the reviewed earthquakes were adopted from Ambraseys et al., ${ }^{47}$ Papazachos and Papazachou, ${ }^{8}$ Papadopoulos et al., ${ }^{39}$ and Papadopoulos, ${ }^{48}$ and are summarized in Table $1 .^{8,39,48-50}$ Classical sources documenting historical earthquake events are listed in Appendix. Localities are illustrated in Figures 1 and 2. Epicenters of the tsunamigenic and nontsunamigenic earthquakes are plotted in Figures 2 and 3, respectively.

\section{Geological investigation of palaeotsunamis}

In middle latitude regions such as the eastern Mediterranean, areas favorable for tsunami sedimentation, preservation and identification are typically low-energy depositional environments, such as coastal wetlands and lagoons, protected from the sea by a sandy barrier which provides the material for re-deposition by the tsunami. ${ }^{51,52}$ Furthermore, the lowenergy conditions of the environment protect the deposit from post-depositional erosion.

Geological evidence for palaeotsunamis was investigated in Rhodes and in Dalaman (Figures 2 and 3). In Rhodes, a field survey performed during July 1997 proved unsuccessful because coastal zones were either highly disturbed by human activities or geologically unsuitable for palaeotsunami trenching. In contrast, the surveyed trenching site in Dalaman (Figures 4 and 5), situated at $28.7560^{\circ} \mathrm{E}, 36.7031^{\circ} \mathrm{N}$ as determined by hand GPS devices, is an undisturbed coastal wetland, due to the presence of a small rivermouth (Figure 4), and protected from the sea by a sandy barrier approximately $160 \mathrm{~m}$ from the present shoreline. The low-energy conditions of the environment protect the deposits from post-depositional erosion. Debris produced by storm surges and consisting of rounded pieces of pumice was found only on the seaward side of the sandy barriers. Pumice is very likely from the Minoan LBA eruption. No pumice was found at the top of the sand spit. These features indicate that the sandy barrier is probably still active and that storm surges are not capable of overtopping it and flooding the landward area. This is consistent with the fact that, according to local people, no storm surge floods the coastal roads on the landward side. In Dalaman, tsunami sediment deposits were investigated during two field surveys performed in summer 1996 and in

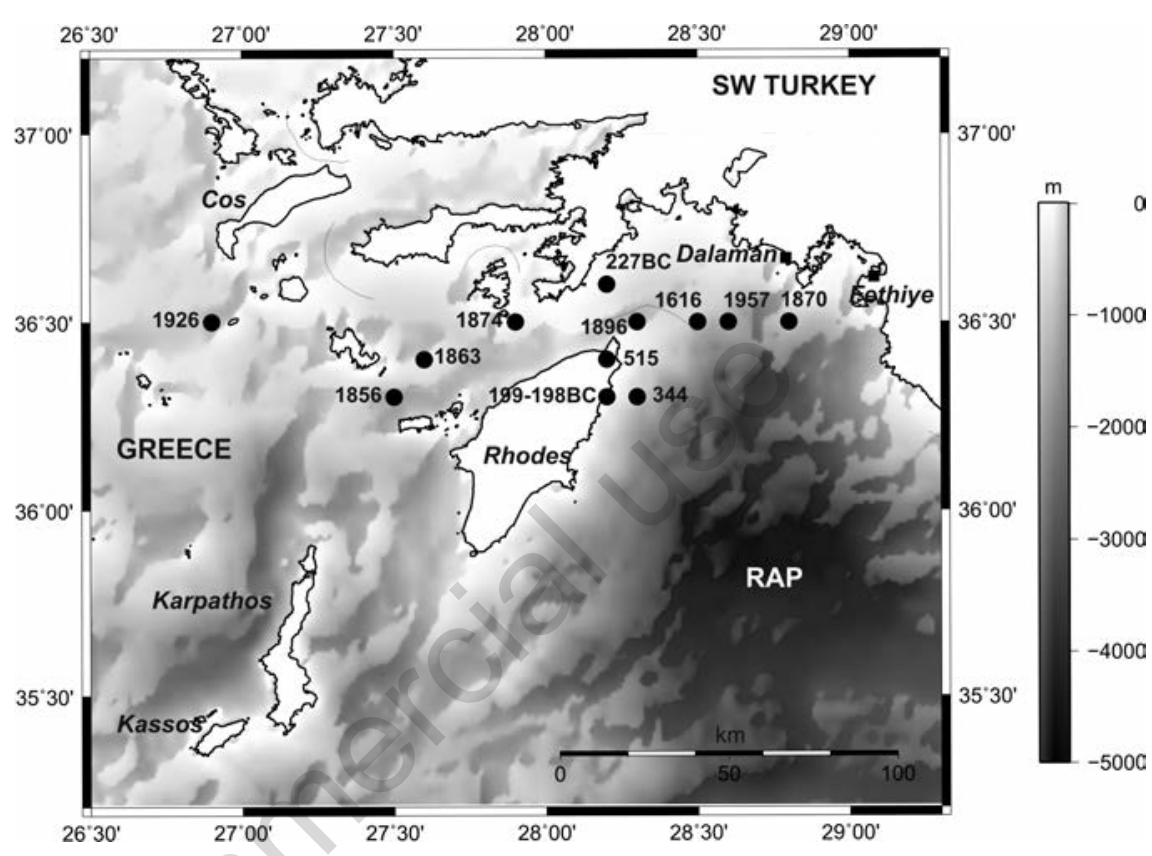

Figure 3. Epicentral locations (solid circles) and year of occurrences of the historical nontsunamigenic earthquakes in the Eastern Hellenic Arc and Trench (EHA-T) and the surrounding regions discussed in the text. RAP, Rhodes Abyssal Plain. Focal parameters of the earthquakes are listed in Table 1.

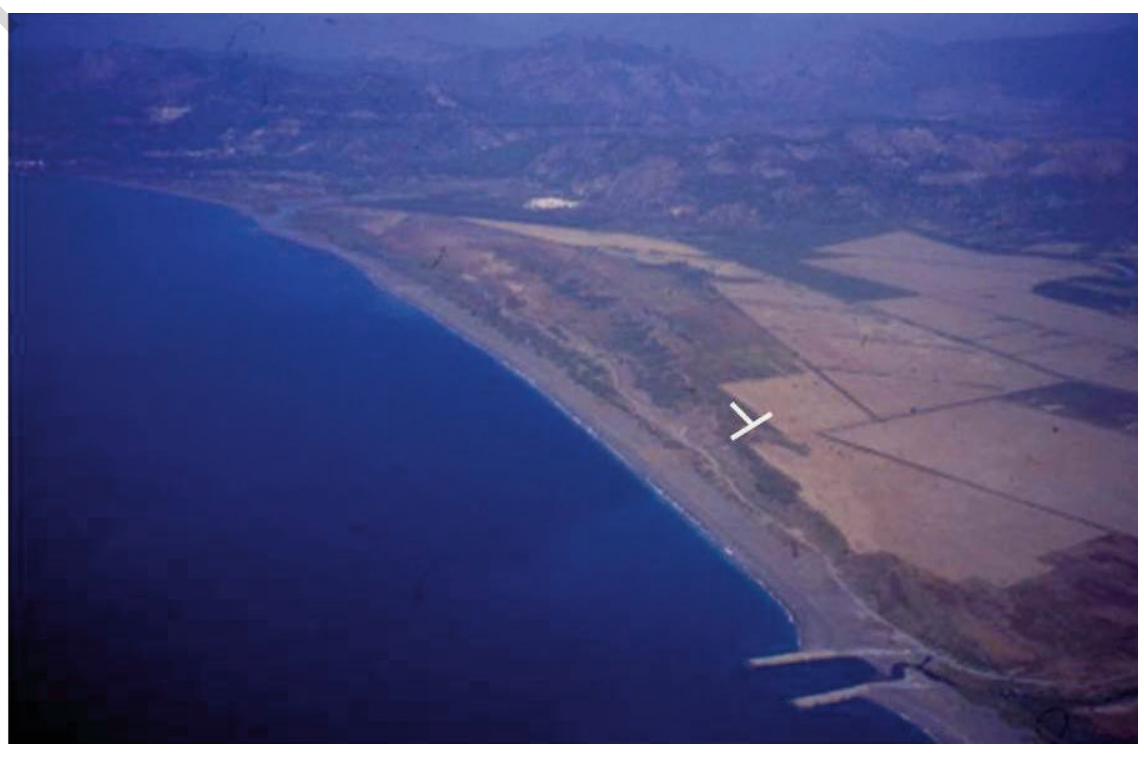

Figure 4. Aerial photograph of the Dalaman alluvium plain in southwestern Turkey. Location of palaeotsunami trenching is marked by white bars. 
Table 1. List of earthquakes discussed in the text. Parameters are taken from Ambraseys and Adams (1998) for the 1926 event and from Papazachos and Papazachou (2003), Papadopoulos et al. (2007) and Papadopoulos (2011) for the other events. Tsunamigenic earthquakes are marked in italics.

\begin{tabular}{|c|c|c|c|c|c|c|c|c|c|c|}
\hline$n$. & $y$ & $m$ & $d$ & $\phi_{N}^{0}$ & $\lambda_{E}^{0}$ & $M_{s}$ & $h(\mathrm{~km})$ & $\begin{array}{c}I_{m} \\
\text { locality }\end{array}$ & Area & Tsunami \\
\hline 1 & $227 \mathrm{BC}$ & & & 36.6 & 28.2 & 7.5 & $?$ & $\begin{array}{c}\text { IX-X } \\
\text { Rhodes }\end{array}$ & & \\
\hline 2 & $199-198$ & & & 36.3 & 28.2 & 7.2 & $?$ & $\begin{array}{c}\text { IX } \\
\text { Rhodes }\end{array}$ & & \\
\hline 3 & $148 A D$ & & & 36.4 & 28.3 & 7.0 & $n$ & $\begin{array}{c}\text { IX-X } \\
\text { Rhodes }\end{array}$ & Rhodes & $\begin{array}{c}\text { Historical } \\
K=7\end{array}$ \\
\hline 4 & 344 & & & 36.3 & 28.3 & 6.5 & $?$ & $\begin{array}{c}\text { VIII } \\
\text { Rhodes }\end{array}$ & & \\
\hline 5 & 515 & & & 36.4 & 28.2 & 6.4 & $\mathrm{n}$ & $\begin{array}{c}\text { IX-X } \\
\text { Rhodes }\end{array}$ & & \\
\hline 6 & $556 A D$ & 08 & & 36.8 & 27.3 & 7.0 & $n$ & $X, \operatorname{Cos}$ & Cos & $\begin{array}{c}\text { Historical } \\
K=8\end{array}$ \\
\hline 7 & 1303 & 08 & 08 & 35.0 & 27.0 & $8.0( \pm 0.3)$ & $n$ & $\begin{array}{c}I X-X \\
\text { Heraklion } \\
\text { Crete }\end{array}$ & $\begin{array}{l}\text { Heraklion } \\
\text { Crete }\end{array}$ & $\begin{array}{c}\text { Historical } \\
\text { Geological } \\
K=9\end{array}$ \\
\hline 8 & 1481 & 05 & 03 & 36.5 & 28.3 & 7.2 & $n$ & VII & Rhodes & $\begin{array}{c}\text { Historical } \\
K=8\end{array}$ \\
\hline 9 & 1609 & 04 & & 36.4 & 28.3 & 7.2 & $n$ & $\begin{array}{c}\text { IX } \\
\text { Rhodes }\end{array}$ & Rhodes & $\begin{array}{c}\text { Historical } \\
K=8\end{array}$ \\
\hline 10 & 1616 & & & 36.5 & 28.5 & 6.4 & $\mathrm{n}$ & $\begin{array}{c}\text { VIII } \\
\text { Rhodes }\end{array}$ & & \\
\hline 11 & 1741 & 01 & 31 & 36.2 & 28.5 & 7.3 & $n$ & $\begin{array}{c}\text { VIII } \\
\text { Rhodes }\end{array}$ & $\begin{array}{c}\text { Rhodes } \\
\text { SW Asia Minor }\end{array}$ & $\begin{array}{c}\text { Historical } \\
K=8\end{array}$ \\
\hline 12 & 1756 & 02 & 13 & 36.3 & 27.5 & 7.5 & i & $\begin{array}{c}\text { VII } \\
\text { Rhodes }\end{array}$ & & \\
\hline 13 & 1851 & 02 & 28 & 36.4 & 28.7 & 7.1 & & $\begin{array}{c}X \\
\text { Makre }\end{array}$ & SW Asia Minor & $\begin{array}{c}\text { Historical } \\
K=3\end{array}$ \\
\hline 14 & 1856 & 10 & 12 & 36.1 & 25.2 & $7.6( \pm 0.3)$ & $\mathrm{i}$ & $\begin{array}{c}\text { IX-X } \\
\text { Heraklio }\end{array}$ & Crete & \\
\hline 15 & 1863 & 04 & 22 & 36.4 & 27.6 & 7.5 & $\mathrm{i}$ & X & Rhodes & \\
\hline 16 & 1870 & 02 & 22 & 36.5 & 28.8 & 6.6 & $n$ & VII & $\begin{array}{c}\text { Makre } \\
\text { SW Turkey }\end{array}$ & \\
\hline 17 & 1874 & 11 & 16 & 36.5 & 27.9 & 7.0 & i & VII & Rhodes & \\
\hline 18 & 1896 & 10 & 27 & 36.5 & 28.3 & 6.4 & $\mathrm{n}$ & VII & Rhodes & \\
\hline 19 & 1926 & 06 & 26 & 36.5 & 26.9 & $7.4 \pm 0.3$ & $115 \pm 10$ & $\begin{array}{c}\text { IX } \\
(\mathrm{MSK})\end{array}$ & cations on Rhodes & \\
\hline
\end{tabular}

\begin{tabular}{llllllll}
20 & 1948 & 02 & 09 & 35.5 & 27.2 & 7.1 & $n$ \\
\hline 21 & 1956 & 07 & 09 & 36.64 & 25.96 & 7.5 & $n$
\end{tabular}

IX Karpathos

Eyewitness accounts $K=7$

IX Cyclades islands

Eyewitness accounts, official and press reports, pictures, tide-gauge records Astypalaea, $K=8$

$\begin{array}{rrrrrrrrrr}22 & 1957 & 04 & 24 & 36.5 & 28.6 & 6.8 & \mathrm{n} & & \text { Rhodes } \\ 23 & 1957 & 04 & 25 & 36.5 & 28.6 & 7.2 & \mathrm{n} & \text { VIII } & \begin{array}{c}\text { Rhodes } \\ \text { Makre }\end{array}\end{array}$

$n$., event code number; $y$, year; $m$, month; $d$, day; $\varphi_{N}^{0}$ geographical latitude; $\lambda_{E}^{0}$ geographical longitude; $M_{s}$ surface-wave magnitude; $h$, focal depth; $n$, normal; $i$, intermediate depth; $I_{m}$, maximum intensity in the Modified-Mercalli 12-point scale, unless otherwise indicated, and locality where $I_{\text {m }}$ was observed; area, location where tsunami was observed; tsunami, short summary of the evidence for the tsunami event; $K$, maximum tsunami intensity in the 12-point scale introduced by Papadopoulos and Imamura (2001). The errors involved in the magnitude and the epicentral determinations of the $20^{\text {th }}$ century earthquakes is in the order of 0.2 and $20 \mathrm{~km}$, respectively, while for historical earthquakes they are as much as 0.5 and $50 \mathrm{~km}$, unless otherwise indicated. The assignment of focal depth to historical earthquakes is not certain due to the little information available, with the possible exception of the events of codes $n$. 14 and 15 . 
summer 2001. In 1996, two palaeotsunami trenches were opened in Dalaman 230-250 m from the present shoreline and at an elevation of approximately $1.5 \mathrm{~m}$ above present mean sea level (msl) on the northern side of the local river. One trench was vertical and the other was parallel to the shoreline (Figure 5). The elevation of each trench was leveled using a Zeiss autoset level. The dimensions of the two trenches were approximately $1 \mathrm{~m}$ in width and $1.5 \mathrm{~m}$ in depth. Their approximate lengths are shown in Figure 5. Similar palaeotsunami trenching was repeated in summer 2001 in a spot situated on the southern side of the local river. However, no evidence for tsunami deposition was found.

The palaeotsunami trenching of 1996 revealed distinct tsunami sediment deposits (Figures 5 and 6). In fact, within the walls of one of the trenches we found three sediment layers approximately $5-15 \mathrm{~cm}$ thick (Figures 6 and 7), sand layers I, II and III, from bottom to top, and situated at an elevation of approximately $+0.30,+0.55$ and $+0.90 \mathrm{~cm}$ from the present msl, respectively.

The three sand layers were intercalated in massive silty mud, which is rich in root impression and yields terrestrial mollusc fossils of genus Helicostyla, Sucinea, Pormatias and Pseudotaches. Common characteristics of the three sand layers include landward thinning as well as sedimentation and erosive contact with the underlying non-marine layer (Figure 6). In addition, each sand layer was composed of coarse sand grains and included an intercalated parting of silty sand, while no structure of sediment grading was observed within the layers. Pumice and marine shell fragments were found in the sand layers.

We interpreted the coastal sequence to have been deposited in the environment of flood plain. These characteristics of sediment facies indicated that the layers of coarse sand were deposited by a high-energy process such as rapid seawater currents. The partings are rich in silty grains, indicating the occurrence of different types of sedimentation during the interval of coarse sand deposition. Landward tapering and sediment fining implied that coarse sand grains were transported inland from the coast. The inclusion of marine shell fragments supported the coastal origin of sand, while the sudden deposition of the sand layers overlying the silty mud suggested catastrophic invasions of seawater. A lack of modern analogs of storms developing such deposits along the coast argues against the possibility that such layers owe their origin to a storm surge. Observation of storm surges on the Aegean Sea coasts suggested that they are generally agents of erosion but do not produce regionally extensive deposits on land areas. ${ }^{14}$ Therefore, we concluded that fast-flowing currents associated with rapid lateral translation of sea water penetrated the coastal zone of Dalaman. The erosive structure and the unusual style of sediment accumulation were well explained by interpreting the coarse sand layers as layers of tsunami origin.

We concluded, therefore, that tsunami waves invaded the coastal plain forming inflow of seawater carrying suspended sediment from the coast. The mineralogical composition of the sand grains in the partings is very similar to that of the coarse sand layers, and the matrix in the partings consists mostly of silt grains originating in the flood plain deposits. The mixture of marine-origin and terrestrial sediment grains in the sand layers is best explained by the forwards and backwards oscillating flow in a multi-wave tsunami, mixing sediment eroded from the near shore littoral environment with sediment eroded from the beach ridge and the floodplain area, perhaps including earlier tsunamigenic sands and liquefied sediment ejected in sand blows. The sandwich-like structure of the sand layers with the muddy silt partings intercalated in the coarse sand material suggested that possibly the deposition of coastal materials by the second invasion of tsunamis preserved the partings. In the wall of one trench perpendicular to Dalaman shoreline, we observed sand dykes connecting layers I and II (Figures 6 and 8). The dykes are filled in with coarse sand grains having their origin in sand layer I. Due to the

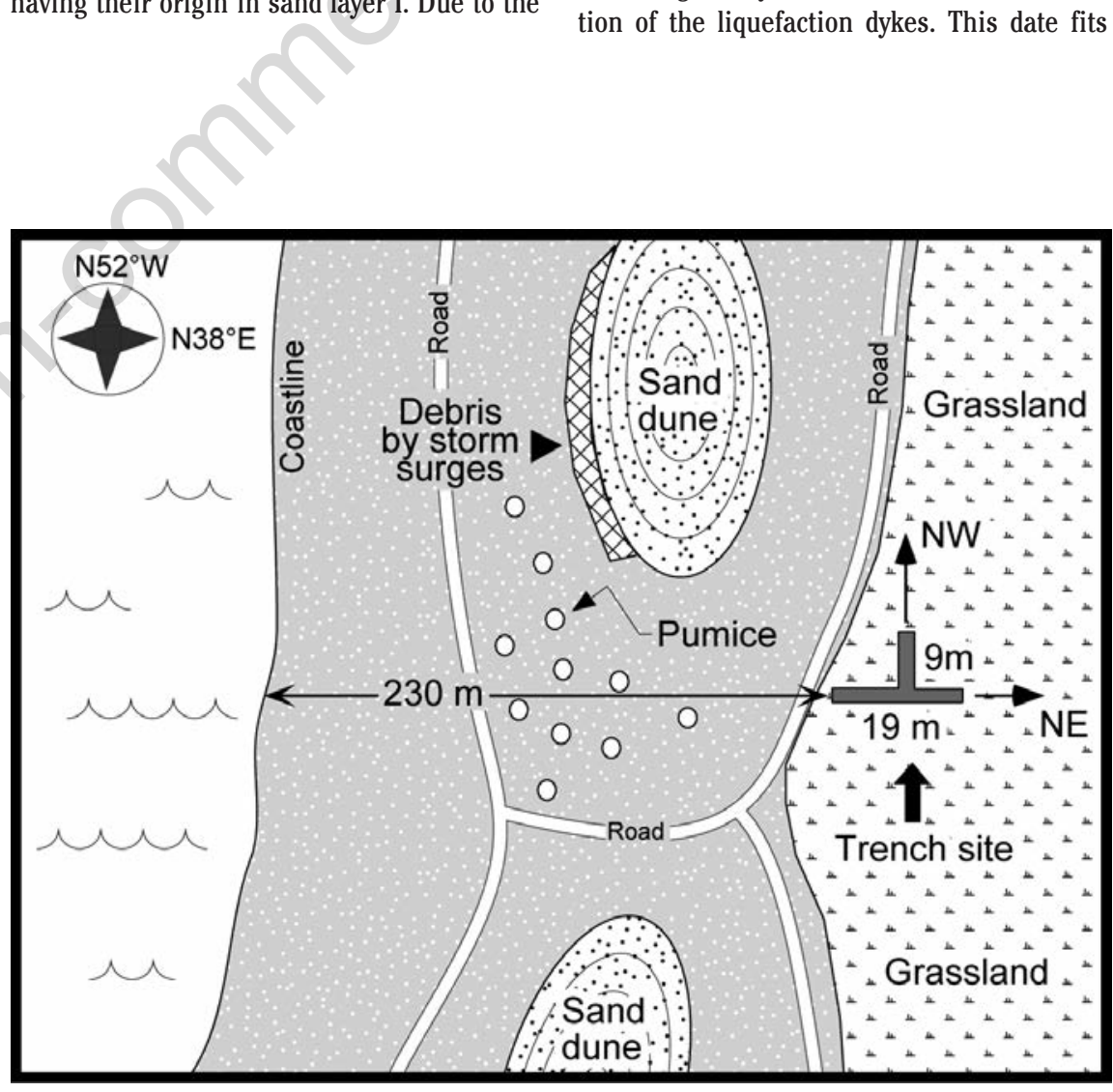

Figure 5. Sketch-map of the palaeotsunami trenching in Dalaman. The stratigraphy section is shown in Figure 6. accretion of grains through the dykes, the thickness of sand layer II increased locally. In contrast, the thickness of sand layer I is reduced in the vicinity of the sand dykes. There was close contact between the dyke walls and the fillings, suggesting that the dyke swarms were due to liquefaction initiated by a strong earthquake. Very possibly, the seismic strong ground motion generated cracks in the coastal plain, through which liquefied sand gushed out onto the surface. We were unable to find any trace of sediment liquefaction in sand layers II and III.

\section{Dating and correlation with historical tsunamis}

In the Dalaman trench we were able to collect a fragment of wood trunk from the upper part of layer II. Radiocarbon ${ }^{14} \mathrm{C}$ accelerator mass spectrometry (AMS) was carried out to date the wood sample (Table 2 ). The $\delta^{13} \mathrm{C}$ value of $-28.1 \%$ indicated that the fragment originated in C3 plant. The radiocarbon age obtained from the sample was calibrated to calendar age using the CALIB program, version 4.3 of Stuiver and Reimer. ${ }^{53}$ The calibrated date of the fragment $(\mathrm{AD} 1473 \pm 46)$ showed the deposition age of layer II but also dated the formation of the liquefaction dykes. This date fits 
fairly well with the historically documented large earthquake and tsunami event of $3^{\text {rd }}$ May 1481.

Since no other material was available for dating, the age of layers I and III was roughly estimated by extrapolation in time. Assuming that the alluvium sedimentation rate, $r$, in the floodplain was constant in the period under discussion, from column B (Figure 6) we calculated $r=0.13 \mathrm{~cm} /$ year. Then, deposition of layer III corresponds to AD 1724 which is not very much earlier than $31^{\text {st }}$ January 1741 , the date of the large earthquake and of the associated tsunami which inundated not only the island of Rhodes, but also penetrated $1 \mathrm{~km}$ inland of the coast opposite the island where Dalaman is situated. By extrapolating calculations to the pre-1481 time period, we found that in columns B and C (Figure 6), layer I was deposited around 1322 which is not very much later than $8^{\text {th }}$ August 1303 when the EHA-T segment was ruptured between Crete and Rhodes by a big tsunamigenic earthquake. Although damage on Rhodes due to the 1303 tsunami is poorly documented, it is reasonable to suggest that the tsunami was powerful enough to reach the scarcely populated, but not so remote coastal zone of Dalaman, and to deposit sand layer I. As a matter of fact, the 1303 earthquake was simulated numerically by several authors and the results showed that although tsunami energy was mainly directed towards the bay of Alexandria, Egypt, south-western Turkey and Rhodes also experienced strong wave effects. ${ }^{54,55,56}$

The Minoan tsunami of the $17^{\text {th }}$ century BC is missing from the stratigraphy retrieved in Dalaman since the stratigraphy record studied represents only the last seven centuries or so. If a uniform rate of sediment deposition in the Dalaman floodplain is assumed, the depth of the Minoan tsunami deposit at Dalaman should be around $4.8 \mathrm{~m}$. In Fethiye and Didim, to the east and northwest of Dalaman, respectively (Figure 1), Minoan tsunami deposits were found at a depth of approximately $1.0 \mathrm{~m}$, which is consistent with the low rates of alluvium deposition prevailing there. ${ }^{14}$

It is noteworthy that, apart from the 1303 , 1481 and 1741 tsunamis, the EHA-T area was also affected by the 1609 tsunami, which does not fit the above chronology and was missing from the trenching stratigraphy. The lack of
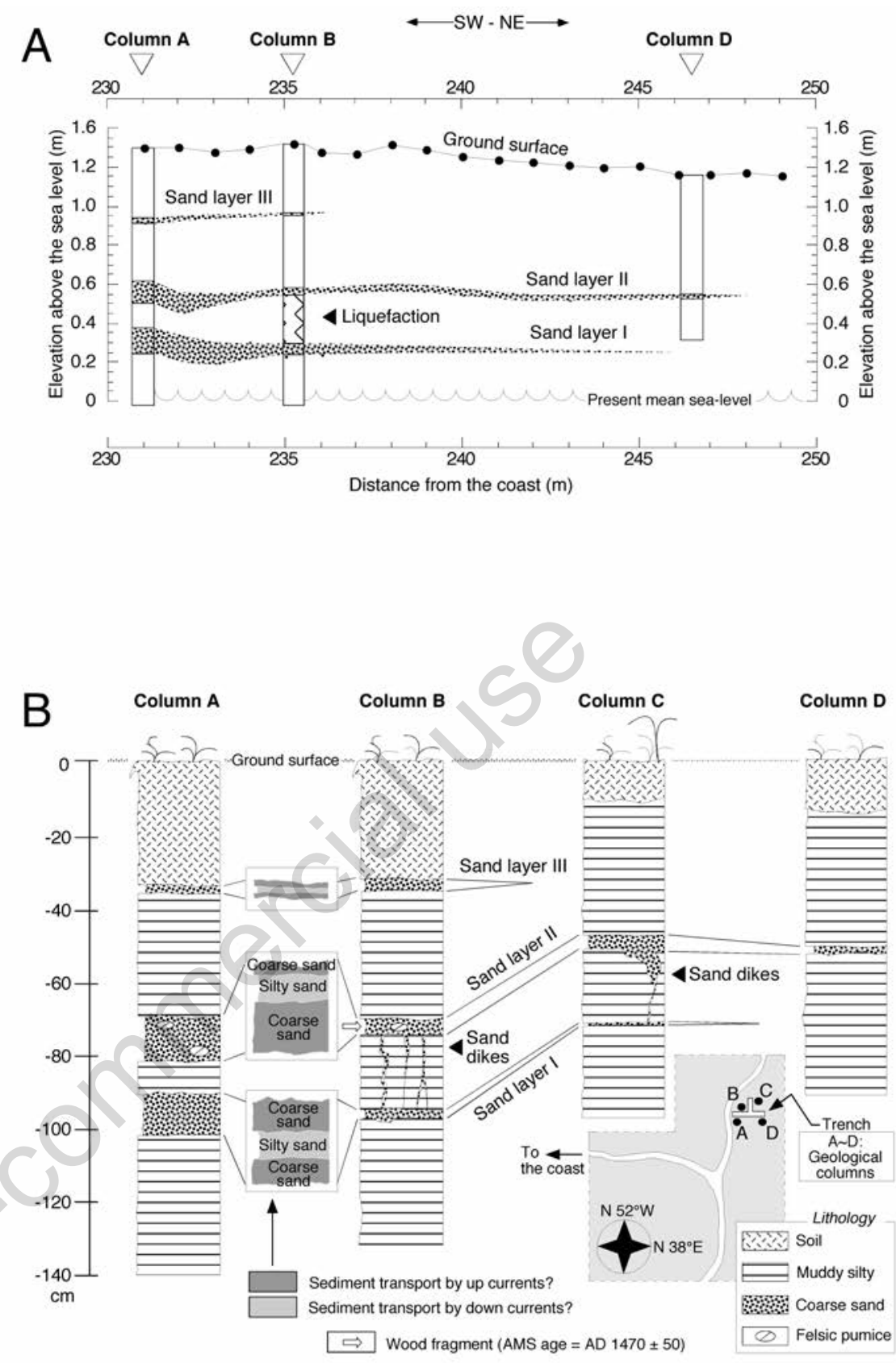

Figure 6. Stratigraphy section of the palaeotsunami trenching in Dalaman. (A) General and $(B)$ detailed view. Three sediment layers of sand were attributed to the 1303,1481 and 1741 historically documented tsunamis. Sand dykes directed upwards from layer I to layer II are attributed to liquefaction of sand layer I due to the large 1481 earthquake that caused the tsunami layer II.

Table 2. Accelerator mass spectrometry ${ }^{14} \mathrm{C}$ radiodating results on the sample from the trench site at Dalaman.

\begin{tabular}{lccccccc}
$\begin{array}{l}\text { Sampling } \\
\text { site }\end{array}$ & Material & $\begin{array}{c}\delta^{13} \mathrm{C} \\
(\%)\end{array}$ & $\begin{array}{c}{ }^{14} \mathrm{C} \text { age } \\
(\text { years BP) }\end{array}$ & $\begin{array}{c}\text { Error } \\
(1 \text { o })\end{array}$ & $\begin{array}{c}\text { Calibrated } \\
\text { age }\end{array}$ & $\begin{array}{c}\text { Error } \\
(1 \sigma)\end{array}$ \\
Dalaman, Site 3 & Wood fragment & -28.1 & 395 & 102 & AD 1473 & 46 & NUTA-5154 \\
\hline
\end{tabular}


1609 tsunami sediment deposits is discussed later. The earthquakes of 1481, 1609 and 1741 caused damage in Rhodes and were strongly felt towards the eastern Mediterranean basin. In addition, the three tsunamis inundated the city of Rhodes and the coasts of southwest Asia Minor to the northeast of Rhodes. Because of these features, we suggested that the sources of the three earthquakes were very likely placed in the Rhodes Abyssal Plain (RAP) (Figure 2). Sea depths of up to $4200 \mathrm{~m}$, along with the thrust component involved in the active seismotectonics in the area of the RAP, favor tsunami generation from large magnitude, possibly interplate earthquakes. The liquefaction in soil caused by the 1481 earthquake constrains the critical epicentral distance needed to place the epicenter in the RAP. Empirical $M / R$ relationships predicting the maximum distance, $R$, at which soil liquefaction may occur regardless of the style of earthquake faulting ${ }^{57}$ were applied to calculate maximum distance for M 7.2, which is the suggested magnitude of the 1481 earthquake. We found $R=125 \mathrm{~km}$, which certainly exceeds the distance of the RAP from the liquefaction spot on the Dalaman coast (Figure 2).

\section{Discussion}

From the earthquake and tsunami history of the EHA-T region it emerges that only the prehistoric large Minoan tsunami, the large tsunami of 1303 , and the tsunamis of 1481 , 1609 and 1741 were powerful enough and had the bearing potential to inundate and deposit sediments in the coastal segment of Dalaman studied. A comparison between the historical and geological record of tsunamis in the EHA$\mathrm{T}$ indicated that the geological record corresponds quite well with the historical tsunami record in the time span covered by the stratigraphy of our trenching. In fact, only the strong tsunami of 1609 was missing from the Dalaman stratigraphy, which, instead, includes sedimentary signatures, which could be attributed to the strong historically documented tsunamis of 1303, 1481 and 1741. Three alternatives may explain why the 1609 wave is missing from the Dalaman stratigraphy: i) the 1609 tsunami failed to inundate the Dalaman coastal zone studied; ii) the tsunami inundated this zone but did not leave behind tsunami deposits in the trenching site; iii) the tsunami inundated and deposited sediment at the trenching site but the sand layers were not preserved there. Importantly, doubts remains on the alluvium sedimentation rate assumed to calculate dates of sediment layers I and III. In fact, alternative sedimentation scenarios could be that some of the tsunami waves eroded the soil in the trenching area before

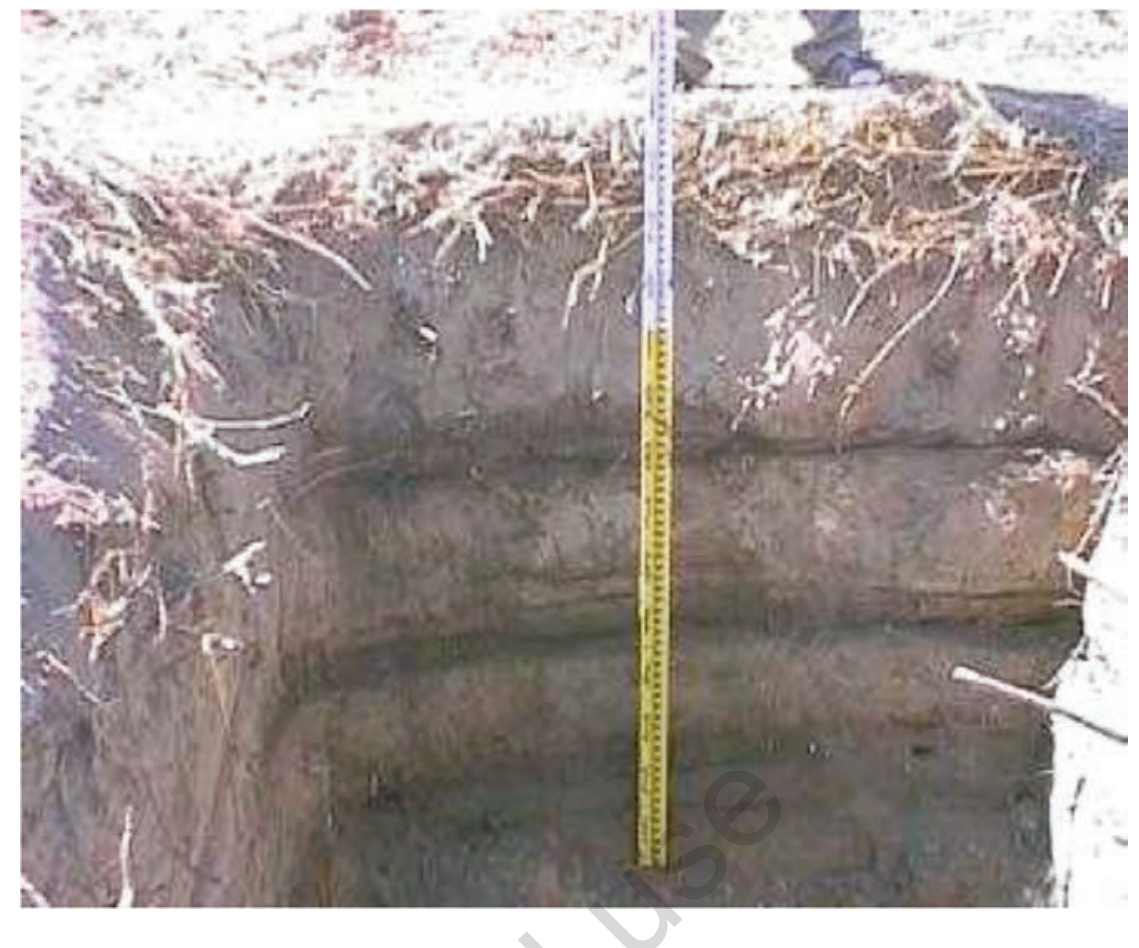

Figure 7. Picture of trench wall with the three-tsunami sediment layers in Dalaman.

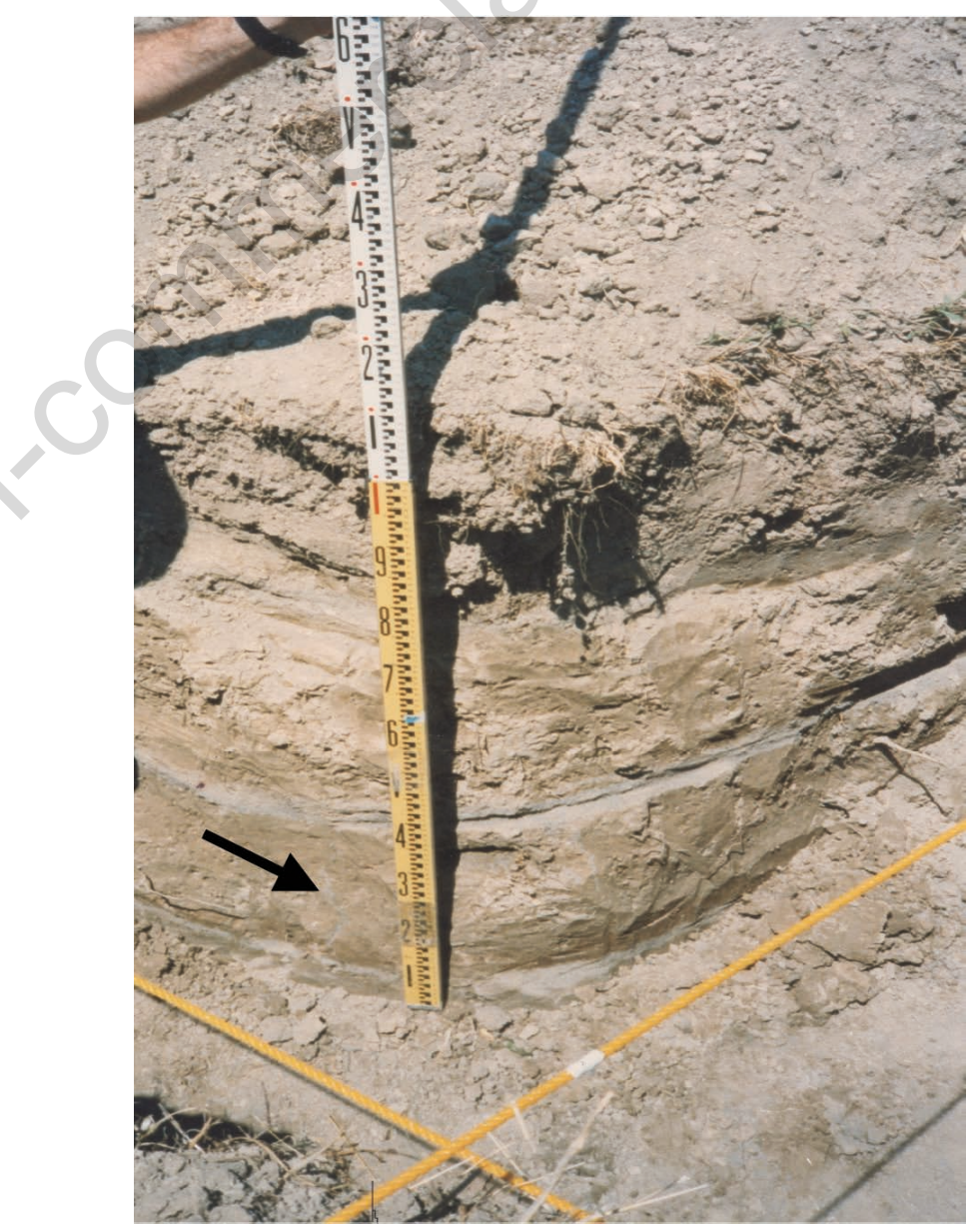

Figure 8. Sand dykes (arrow) connecting layers I and II in the Dalaman trenching site and indicating liquefaction of sand layer I due to the earthquake of 1481, which caused the tsunami that deposited layer II. 
depositing their sediments. If so, then the inferred sedimentation rate should have been higher than that calculated, and the dating of layers I and III may shift. If the sedimentation rate is higher, then this may be the 1609 signature, and then the 1741 would be missing. However, only a substantial change in sedimentation rate would be required to make sand layer I as old as the $556 \mathrm{AD}$ tsunamigenic earthquake that hit the island of Rhodes. On the other hand, a decrease in sedimentation rate with time would imply that sand layer I is significantly younger than 1303 .

Consequently, the geological record of tsunamis appears to be extremely sensitive to several possible factors. In Fethiye (Figure 2), only about $20 \mathrm{~km}$ to the east of Dalaman, we were able to identify only Late Bronze Age tsunami deposits associated with the Minoan tsunami of Thera. ${ }^{14}$ In the village of Kamari, on the east coast of the island of Thera, several archaeological trenches were studied but no tsunami traces were found there. ${ }^{58} 0 \mathrm{n}$ the contrary, at a distance of no more than $500 \mathrm{~m}$ from one of the investigated trenches, our team was able to identify a sand layer attributed to the large tsunami of $29^{\text {th }}$ September 1650 (Julian calendar) associated with an eruption of the extra-caldera submarine Columbos volcanic edifice. ${ }^{11}$ The sensitivity of the tsunami sediment deposition is strongly controlled by factors such as local topography and coastal configuration, as well as local conditions for sediment deposition and preservation and for ground erosion. Sand layer II was much thicker than sand layer III and penetrated inland for a longer distance (Figure 6). This difference may indicate that in Dalaman a stronger tsunami inundated the coast in 1481 than in 1741. To check the elevation of the tsunami sediment layers at the time of deposition it is of relevance to calibrate elevation against past msl. Flemming and $\mathrm{Webb}^{59}$ derived a best estimate of the eustatic sea level curve for the Mediterranean Sea corrected for local tectonic movements. This curve suggests a rapid rise of sea level up to approximately 5-6 ka BP, followed by a slow rise of sea level of approximately $1 \mathrm{~m}$ from $4 \mathrm{ka} \mathrm{BP}$ onwards. Besides this, according to palaeoshorline and archaeological data, synthesized by Palyvos et al., ${ }^{60}$ there has been a rise in msl of approximately $1.5 \mathrm{~m}$ in the Mediterranean Sea over about the last 4000 years. In Greece, a rise in msl of approximately $1 \mathrm{~mm} /$ year was found in the last 6000 years. In the western Anatolia coast, Kayan $(1988)^{61}$ found that, since $3000 \mathrm{BC}$, the sea level has risen to the present position generally. These results imply that at the time of sand layer deposition at Dalaman the sea level may have been less than an average $1 \mathrm{~m}$ lower than it is today.

Although the strong earthquakes of 1303 , 1481, 1609 and 1741 were tsunamigenic, other strong EHA-T earthquakes were not. The 1851 strong earthquake was possibly associated with only a small-to-moderate local tsunami. The 1957 large earthquake (M7.2) was a nontsunamigenic event. Therefore, one of the most challenging fields for future research is to examine why in a particular seismotectonic segment, such as the East Hellenic Arc and Trench, some of the strong earthquakes produce tsunamis and others do not.

The palaeotsunami study we performed in EHA-T is of importance for a number of reasons: i) it yields independent geological evidence for historically documented earthquake and tsunami events; ii) it adds additional information to the tsunami run-up database, which is the cornerstone of tsunami risk assessment, of an area where tsunami risk has increased dramatically in around the last $\mathbf{5 0}$ years due to a rapid increase in building construction, tourism and other human activities; iii) from a methodological point of view, it further tests the possibilities and limitations of palaeotsunami investigative methods.

\section{Conclusions}

On the test site of Dalaman, south-western Turkey, trenching at distance from 230 to 250 $\mathrm{m}$ from the present shoreline revealed three layers of tsunami sediment deposits at elevations of approximately $+0.30,+0.55$ and +0.90 $\mathrm{cm}$ above present msl.

Sand dykes, filled in with coarse sand grains and originated in sand layer I, connect layers I and II. Consequently, the earthquake that triggered the tsunami depositing sand layer II caused liquefaction in sand layer I. AMS ${ }^{14} \mathrm{C}$ dating in a wood sample collected from layer II showed deposition in $\mathrm{AD} 1473 \pm 46$, which fits quite well with the historically documented $3^{\text {rd }}$ May 1481 strong earthquake and tsunami event. Extrapolating a roughly estimated average alluvium deposition rate of $0.13 \mathrm{~cm} /$ year, layers I and II were dated to AD 1322 and 1724, respectively. These dates are not far distant from the dates of the 1303 and 1741 historical earthquake and tsunami events. The sedimentary record in Dalaman not only documents geologically historical tsunamis of the area, but also further extends our knowledge as regards the inundation of historical tsunamis in coastal zones of the eastern Mediterranean Sea. In fact, documentary sources indicated that the 1481 tsunami flooded the coastal zone of Rhodes but the geological record, represented by sand layer II, adds that the tsunami inundated the opposite mainland as well, penetrating inland for around $250 \mathrm{~m}$ in Dalaman. As for the 1741 tsunami, the geological record represented by sand layer III, appears to verify the historical description ${ }^{47}$ that the sea in Rhodes retreated and then flooded the coast twelve times with great violence, submerging the coast opposite the island, and destroying five or six villages located a kilometer inland. It is reasonable to suggest that ... the coast opposite the island... ${ }^{32}$ includes Dalaman and other coastal localities in SW Asia Minor. Sand layer I is one of the very few possible geological signatures known so far for the large 1303 tsunami.

\section{References}

1. McKenzie DP. Plate tectonics of the Mediterranean region. Nature 1970;226: 239-43.

2. McKenzie DP. Active tectonics of the Mediterranean region, Geophys J R Astron Soc 1972;30:109-85.

3. Le Pichon X, Angelier J. The Hellenic Arc and Trench System: a key to the neotectonic evolution of the Eastern Mediterranean Area. Tectonophysics 1979;60:1-42.

4. Reilinger R, McClusky S, Vernant P, et al. GPS constraints on continental deformation in the Africa-Arabia-Eurasia continental collision zone and implications for the dynamics of plate interactions. $J$ Geophys Res 2006;11:B05411.

5. McClusky S, Balassanian S, Barka A, et al. Global Positionig System constraints on plate kinematics and dynamics in the eastern Mediterranean and Caucasus. J Geophys Res 2000;105:5695-719.

6. Rotstein Y, Kafka AL. Seismotectonics of the southern boundary of Anatolia, eastern Mediterranean region: subduction, collision, and arc jumping. J Geophys Res 1982;87:7694-706.

7. Papadopoulos GA, Kondopoulou D, Leventakis GA, Pavlides S. Seismotectonics of the Aegean region. Tectonophysics 1986;124: 67-84.

8. Papazachos BC, Papazachou C. The Earthquakes of Greece. Thessaloniki: Ziti editions; 2003. [In Greek].

9. Kahle HG, Cocard M, Peter Y, et al. GPSderived strain rate field within the boundary zones of the Eurasian, African, and Arabian Plates. J Geophys Res 2000;105: 23353-70.

10. Papadopoulos GA, Fokaefs A. Strong tsunamis in the Mediterranean Sea: a reevaluation. ISET J Earthq Technol 2005;42: 159-70.

11. Papadopoulos GA. Tsunamis. In: Woodward J, ed. Physical Geography of the Mediterranean. Oxford: Oxford University Press; 2009. pp 493-512.

12. Pirazzoli PA, Ausseil-Badie J, Giresse P, et al. Historical environmental changes at Phalasarna harbour, west Crete. Geoarchaeology 1992;7:371-92. 
13. Dominey-Howes D, Dawson A, Smith D. Late Holocene coastal tectonics at Falasarna, W. Crete: a sedimentary study. In: Stewart IJ, Vita-Finzi C, eds. Coastal tectonics. London: Geological Society, Special Publications; 1998;146. pp 343352.

14. Minoura K, Imamura F, Kuran U, et al. Discovery of Minoan tsunami deposits. Geology 2000;28:59-62.

15. McCoy FW, Papadopoulos G. Tsunami generation during the Late Bronze Age eruption of Thera: evidence from Tsunami deposits on Thera, Crete, West Turkey and the Deep Sea [abstract]. Am J Arch 2001;105:258-9.

16. Bruins HJ, MacGillivray JA, Synolakis CE, et al. Geoarchaeological tsunami deposits at Palaikastro (Crete) and the Late Minoan IA eruption of Santorini. J Arch Sci 2008;35:191-212.

17. McCoy FW, Heiken G. Tsunami generated by the Late Bronze Age eruption of Thera (Santorini), Greece. Pure Appl Geophys 2000;157:1227-56.

18. Goodman-Tchernov BN, Dey HW, Reinhardt EG, et al. Tsunami waves generated by the Santorini eruption reached Eastern Mediterranean shores. Geology 2009;37:943-6.

19. Kontopoulos N, Avramidis P. A late Holocene record of environmental changes from the Aliki lagoon, Egion, North Peloponnesus, Greece. Quat Int 2003;11:75-90.

20. Kortekaas S, Papadopoulos GA, Ganas A. Geological identification of historical tsunamis in the Gulf of Corinth, Central Greece. Proc Int Symposium on Natural \& Human-Made Hazards; 2002 October 3-6; Antalya, Turkey, pp. 133-134.

21. Kortekaas S, Papadopoulos GA, Ganas A, et al. Geological identification of historical tsunamis in the Gulf of Corinth, Central Greece. Nat Hazards Earth Syst Sci 2011;11:2029-41.

22. Georgiades AS. Peri Seismon kai Kataskevis Antiseismikon Oikodomimaton (About Earthquakes and the Construction of Antiseismic Buildings). Athens: S. Kousoulinos; 1904. p 306. [In Greek].

23. Sieberg A. Untersuchungen uber Bruchschollenban im östlichen Mittelmeergebiet. Jena: Denkschriften der Medizinish-Naturwissenschaftlichen Gesellschaft zu Jena 2.; 1932.

24. Galanopoulos AG. Tsunamis observed on the coasts of Greece from Antiquity to present time. Ann Geofis 1960;13:369-86.

25. Ambraseys NN. Data for the investigation of the seismic sea-waves in the eastern Mediterranean. Bull Seismol Soc Am 1962;52:895-913.

26. Ambraseys N. Earthquakes in the
Mediterranean and Middle East, a multidisciplinary study of seismicity up to 1900 . Cambridge, UK: Cambridge University Press: 2009. pp. 947.

27. Antonopoulos J. Data from investigation on seismic sea-waves events in the Eastern Mediterranean from the birth of Christ to 1980 AD (six parts). Ann Geofis 1980;33:141-248.

28. Papadopoulos GA, Chalkis BG. Tsunamis observed in Greece and the surrounding area from antiquity up to present times. Mar Geol 1984;56:309-17.

29. Soloviev SL. Tsunamigenic zones in the Mediterranean Sea. Nat Hazards 1990;3:183-202.

30. Kuran U, Yalçiner AC. Crack propagations, earthquakes and tsunamis in the vicinity of Anatolia. In: Tinti S, ed. Tsunamis in the world. Adv. Nat. Technol. Hazards Res. Dordrecht: Kluwer Academic Publishers; 1993. pp 159-175.

31. Guidoboni E, Comastri A, Traina G. Catalogue of ancient earthquakes in the Mediterranean area up to the 10th century. Rome: Istituto Nazionale di Geofisica; 1994.

32. Ambraseys NN, Finkel CF. The seismicity of Turkey and adjacent areas, a historical review, 1500-1800. Istanbul: EREN Ltd; 1995.

33. Papazachos BC, Papazachou C. The Earthquakes of Greece. Thessaloniki: Ziti editions; 1997.

34. Guidoboni E, Comastri A. The large earthquake of 8 August 1303 in Crete: seismic scenario and tsunami in the Mediterranean area. J Seismol 1997;1:5572.

35. Guidoboni E, Comastri A. Catalogue of earthquakes and tsunamis in the Mediterranean area, 11th-15th century. Rome: Istituto Nazionale di Geofisica e Vulcanologia; 2005.

36. Altinok Y, Ersoy S. Tsunamis observed on and near the Turkish Coast. Nat Hazards 2000;21:185-205.

37. Soloviev SL, Solovieva ON, Go CN, et al. Tsunamis in the Mediterranean Sea 2000 BC - 2000 AD advances in natural and technological hazards research (13). London: Kluwer Academic Publichers; 2000. pp. 237.

38. Papadopoulos GA. Tsunamis in the East Mediterranean: a catalogue for the area of Greece and adjacent seas. Proc Joint IOCIUGG Int Workshop "Tsunami Risk Assessment beyond 2000: Theory, Practice and Plans"; 2000 Jun 14-16; Moscow, Russia, 2001. pp 34-43.

39. Papadopoulos GA, Daskalaki E, Fokaefs A, Giraleas N. Tsunami hazard in the Eastern Mediterranean: strong earthquakes and tsunamis in the East Hellenic Arc and
Trench System. Nat Hazards Earth Syst Sci 2007;7:57-64.

40. Tinti S, Maramai A. Catalogue of tsunamis generated in Italy and in Cote d'Azur, France: a step towards a unified catalogue of tsunamis in Europe. Ann Geofis 1996;39:1253-99.

41. Papadopoulos GA. Tsunami hazard in the Eastern Mediterranean: strong earthquakes and tsunamis in the Corinth Gulf, Central Greece. Nat Hazards 2003;29:43764.

42. De Martini P, Barbano MS, Smedile A, et al. A unique 4000 year long geological record of multiple inundations in the Augusta Bay (eastern Sicily, Italy). Mar Geol 2010;276:42-57.

43. Cita MB, Camerlenghi A, Kastens KA, McCoy FW. New findings of bronze age homogenites in the Ionian sea: geodynamic implications for the Mediterranean. Mar Geol 1984;55:47-62.

44. Cita MB, Aloisi G. Deep-sea tsunami deposits triggered by the explosion of Santorini (3500 y BP), eastern Mediterranean. Sedim Geol 2000;135:181203.

45. Papadopoulos GA. Statistics of historical earthquakes and associated phenomena in the Aegean and surrounding regions. Proc Int Symposium Engin Geology as Related to the Study, Preservation \& Protection of Ancient Works, Monuments \& Historical Sites; Balkema, Athens: Marinos P, Koukis G editors; 1988. pp 1279-1283.

46. Papadopoulos GA, Daskalaki E, Fokaefs A, Giraleas N. Tsunami hazard in the Eastern Mediterranean sea: strong earthquakes and tsunamis in the west Hellenic arc and trench system. J Earthq Tsunami 2010;4:145-79.

47. Ambraseys NN, Melville CP, Adams RD. The Seismicity of Egypt, Arabia and the Red Sea: a historical review. Cambridge: Cambridge University Press: 1994. pp. 181.

48. Papadopoulos GA. A seismic history of Crete, the central segment of the Hellenic Arc and Trench-Earthquakes and Tsunamis BC 2000 - 2010. Athens: Ocelotos; 2011.

49. Ambraseys NN, Adams RD. The Rhodes earthquake of 26 June 1926. J Seismol 1998;2:267-92.

50. Papadopoulos GA, Imamura F. Proposal for a new tsunami intensity scale. Proc 20th Int Tsunami Conf; Seattle, 7-9 Aug. 2001. pp 569-577.

51. Dawson AG, Shi S, Dawson S, et al. Coastal sedimentation associated with the June 2nd and 3rd, 1994 tsunami in Rajegwesi, Java. Quat Sci Rev 1996; 15:901-12 
52. Morton RA, Gelfenbaum G, Jaffe BE Physical criteria for distinguishing sandy tsunami and storm deposits using modern examples. Sedim Geol 2007;200:184-207.

53. Stuiver M, Reimer PJ. Extended $14 \mathrm{C}$ data base and revised calib 3.0 14C age calibration program. Radiocarbon 1993;35:21530 .

54. Tinti S, Armigliato A, Pagnoni G, Zaniboni F. Scenarios of giant tsunamis of tectonic origin in the Mediterranean. ISET $\mathrm{J}$ Earthq Technol 2005;42:171-88.

55. Hamouda AZ. Numerical computations of 1303 tsunamigenic propagation towards Alexandria, Egyptian Coast. J Afr Earth Sci 2006;44:37-44.
56. Yolsal S, Taymaz T, Yalçiner AC. Understanding tsunamis, potential source regions and tsunami-prone mechanisms in the Eastern Mediterranean. London: Geological Society, Special Publications; 2007;291. pp 201-230.

57. Papadopoulos GA, Lefkopoulos G. Magnitude-distance relations for liquefaction in soil from earthquakes. Bull Seismol Soc Am 1993;83:925-38.

58. Dominey-Howes D, Papadopoulos GA, Dawson AG. Geological and historical investigation of the $1650 \mathrm{Mt}$. Columbo (Thera Island) eruption and tsunami, Aegean Sea, Greece. Nat Hazards 2000;21:83-96.
59. Flemming NC, Webb CO. Tectonic and eustatic coastal changes during the last 10,000 years derived from archaeological data. Zeitschrift für Geomorphologie N.F. 1986;62:1-29.

60. Palyvos N, Lemeille F, Sorel D, et al. Geomorphic and biological indicators of paleoseismicity and Holocene uplift rate at a coastal normal fault footwall (western Corinth Gulf, Greece). Geomorphology 2008;96:16-38.

61. Kayan I. Late Holocene sea-level changes on the western Anatolian coast. Palaeogeogr Palaeoclimatol Palaeoecol 1988;68:205-18. 